\title{
Golbanov A.E., Neverova A.V. The significance of the problem of violence for political life, its difference from other political means
}

The Institute of Service and Business (branch) DSTU

(Russia, Shakhty)

doi: $10.18411 / \mathrm{lj}-05-2019-132$

idsp: ljournal-05-2019-132

\section{Abstract}

This article explores the democratic and dictatorial regime, in historical and legal aspects. Particular attention is paid to a comparative analysis of legal regimes typical for these political regimes, and the development and formation of these forms of organization of political power is also considered.

Keywords: democracy, dictatorship, political regime, power, research, history.

\section{Аннотация}

Данная статья исследует демократический и диктаторский режим, в исторических и правовых аспектах. Особое внимание уделено сравнительному анализу правовых режимов, характерных для этих политических режимов, а также рассмотрено развитие и становление данных форм организации политической власти.

Ключевые слова: демократия, диктатура, политический режим, власть, исследование, история.

Throughout its history all mankind is aware of countless different political systems, which are the basis of political regimes developed in different eras by many peoples and cultures. If we generalize all political regimes, they can be divided into democratic and dictatorial. As a rule, democracy is seen as the ideal political system, once created by human experience. Dictatorships exist as long as democracies. Almost until the recent years, the vast majority of humankind was under a dictatorial regime. The opposing regime was a democratic legal order.

The following concepts are synonymous with the word "dictatorship": "totalitarianism", "tyranny", "despotism", "authoritarianism", etc., because, as it is believed that the policy of the regimes implied by them is based exclusively on violence and mass terror.

However, despite the prevalence of such judgments, not all dictatorships in the exercise of political power use mass terror and violence; many of them build a successful economic policy (as for example, the dictatorship of the Chilean leader Augusto Pinochet), unite people together on religion grounds, stick to the traditional habit of obeying the strongest, etc. It is worth understanding that totalitarianism and authoritarianism are special forms of dictatorship that appeared in political history in the XX century, but similar features are known in the earlier periods of history.

In our time, the constitutions of such States as the USA, the Great Britain, Germany, France, Switzerland, etc., provide for a temporary dictatorship as a limited emergency institution of power. However, there is a danger that such emergency legislation can lead to absolute dictatorship: Napoleon Bonaparte, Benito Mussolini, Miklos Horti and many other prominent politicians annihilated the democratic rule of law at the expense of its own means.

The dictatorial regime, by its nature, is the ultimate concentration of power, the antipode of democracy. In democracy, a certain core of a huge social organism is the autonomy of the individual. Ensuring human rights is the main aim of democracy. Under dictatorial rule, the situation is quite different because a person as a citizen is in a constant state of oppression. Thus follows the theory of Neo-Marxism from the German philosopher Herbert Marcuse, denoting such a type of authoritarian personality.

The authoritarian personality itself does not have the proper measure of independence of actions and judgments. When faced with social problems, it seeks salvation in the strictest moral 
codes provided by the current dictatorship, as well as in the willingness to obey authorities. With the help of force, unleashing mass terror, explicit or implicit threats, the dictator tries to gain despotic control over the masses opposing his power. Any violation of the freedoms of citizens, and often despotic terror are among the methods of establishing autonomous domination.

The use of mass media to create the necessary public opinion is used by dictatorial regimes more often than by democratic ones. A characteristic feature of democracy is pluralism, pluralism in all spheres of life whether political, ideological or spiritual. The division of powers into legislative, executive and judicial is also one of the signs inherent in the democratic regime. The dictatorship rejects any manifestation of pluralism. Political struggle ceases to exist and turns into "behind-the-scenes maneuvers", turning into bloody conflicts of the opposing parties seeking to eliminate each other once and for all from the political arena.

Democracy has always been based on the rule of law. It considered the rule of law as a sanctuary capable of suppressing any conflicts. In the conditions of despotic dictatorship this rule cannot be fulfilled. In any case, no dictatorship can do without legislative codes, but their existence is only a formality, because dictators often act in circumvention of the laws established by them and violate them in every possible way. The overwhelming number of dictators who follow the Constitution in the field of formal rules violate it in terms of guarantees of personal rights and freedoms of citizens.

At all times, the problem of political violence has been an object of attention from various philosophers, sociologists, political scientists, etc. The widespread mass violence and its devastating consequences give relevance to this problem. According to the data of the Stockholm Peace Research Institute there are more than 30 bloody armed conflicts of an internal nature all over the world. In 1994 inter-ethnic clashes claimed the lives of between 200,000 and 500,000 people, according to various estimates.

The problem of violence is of particular importance for the political life of Russia. It always played a great role: at the stage of formation of the monarchy and in the period of totalitarianism and in the most modern conditions. And what after all is violence as a means of exercising power? Power relations presuppose unfair inequality between the object and the subject of power. Frankly speaking, political power is based on absolute domination of dominants and strict subordination of others.

Violence is only one means of exercising power, but most political scientists tend to believe that violence is an attribute of power that gives it high-level certainty. This is what practice shows. In the XX century, political power was realized in the form of complete domination of the ruling entity. Under these circumstances violence was the basis of state authority.

The use of violence must be stopped by humane treatment. Violence should not be accompanied by acts of every kind of abuse of those to whom it is directed. Persons who have renounced political struggle (arrested, imprisoned ones, etc.) should be guaranteed the full right to inviolability and decent treatment. The subjects of violence should not violate the fundamental rights and freedoms of a person and a citizen. For the state authorities themselves, this means that violence should be carried out only in accordance with laws, that is, norms adopted democratically and having equal obligation for all citizens.

These norms must be fully based on fundamental human rights! Reckless and lawless violence is unacceptable! That is why dictatorial terror looks absolutely unjustified strongly violating all the principles of humanity. International standards (in particular, The Hague and Geneva Conventions) should be the main reference point for the activities of politicians. They protect the rights of all civilians in every way. The humanization of violence is a difficult but solvable task for any state. If we ignore the overcoming of this political barrier, it is possible to lose the democratic content of political actions completely, which will entail irreparable damage to society.

Nevertheless, in various modern societies, declaring the unconditional value of any human life, there are different rights to individual violence (both in democracy and in 
dictatorship), and these rights are regulated in detail. For example, security guards are allowed to use violence against offenders and police officers on duty are also allowed to use violence against the offenders.

One of the causes of political violence is in the socio-cultural sphere. Between the emerging value-normative system of a democratizing society and the intensification of extremist forms of political opposition, there are links that determine the possibility of political violence. The dominant political culture in a particular society is designed to ensure the legitimacy of the existing state power to justify all its actions. Reduction the number of acute conflicts in society, including the use of violence is the successful implementation of this task. With regard to the total destruction of the whole system of values it is normative justification of the political and social system and it is nothing but a source of political violence. If this process does not contribute to improving the welfare of society, the vast majority of citizens loses faith in this kind of legitimacy of the political regime, lose the belief that the rulers need to be obeyed. As a consequence, opposition forces are beginning to form, filling the spiritual deficit of individuals and groups that are alienated from the political system.

The huge range of violence can be attributed not only to the decline of the value system, but also, in general, to the values of the political culture that prevails in society. Thus, political violence is a multifaceted phenomenon, and therefore requires a thorough systematic approach to its study and further application. The peculiarity of political violence is that there is always a high degree of risk of its use as a deadly weapon that harms the whole society. Political activities related to violence are characterized by high emotional tension. On the one hand, the subjects of violence are often guided by emotions and feelings that have reached a violent degree of manifestation: anger, rage, hatred, despair. On the other hand, the consequences of violence cause a corresponding emotional reaction of the objects of violence. Humiliation of dignity, pain and grief generate not only fear, but also hatred, a sense of revenge.

Unfortunately, our century has not become an era of complete triumph of democratic values. As before, the vast majority of the population of our planet lives in the conditions of the most severe tyranny, in the conditions of authoritarian and totalitarian dictatorships. The latter are becoming fewer; almost all the remaining dictatorial regimes are authoritarian and exist in the "Third World". But in general, today we can say that the new situation in the world is conducive to the transition from bloody dictatorial regimes to perfect democracy!

$$
\text { *** }
$$

1. Вилков А.А. Политическое управление и гражданское общество в современной России // Известия Саратовского университета. Сер.: Социология. Политология. 2010. Вып. 4, т. 10 . С. 62-70.

2. Шестов Н.И., Барашков Г.М. Гражданское общество и его аналоговые формы // Известия Саратовского университета. Новая серия. Сер.: Социология. Политология. 2011. Вып. 2, т. 11. С. 71-78.

3. Локк Дж. Два трактата о правлении. URL: www.civisbook.ru/files/File/Lokk.Traktaty_2.pdf

4. O’Connor J., Olsen G. Power Resources Theory and the Welfare State: A Critical Approach. Toronto, 1998.

5. Bengtsson E. Can Power Resources Theory Explain Variations in Labor's Share of National Income? URL: www.researchgate.net/publication/265974147_Can_Power_Resources_Theory_ Explain_Variations_in_Labor's_Share_of_National_Income

6. Анализ социально-политического (властного) общения, диалектики процесса совокупной деятельности людей (процесса общения) и институционального формирования организованных общностей см. в работах: Ильин М. В. Слова и смыслы: общение и общность. - "Полис", \994, № 6; Каган М. С. Мир общения: Проблема межсубъектных отношений. М., 1988.

7. Бурдье П. Социология политики. М., 1993, с. 57.

8. Бергер П., Лукман Т. Социальное конструирование реальности. М., 1995, с. 178 